\title{
Yield and Nutritive Value of Grain, Glumes and Straw of Triticum dicoccum Produced by Prehistoric Technology in Comparison to T. aestivum Produced by Modern Technology
}

\author{
Michal Hejcman ${ }^{\mathrm{a}, \mathrm{b}^{*}}$, Pavla Hejcmanovác \\ ${ }^{a}$ Department of Ecology, Faculty of Environmental Sciences, Czech University of Life Sciences, Kamýcká 1176, CZ-165 21 Prague 6 - Suchdol, Czech Republic \\ ${ }^{b}$ Department of Archaeology, Faculty of Arts, University of Hradec Králové, Rokitanského 62, CZ-500 03 Hradec Králové, Czech Republic \\ ${ }^{c}$ Faculty of Tropical AgriSciences, Czech University of Life Sciences, Kamýcká 129, Prague 6-Suchdol, 16521, Czech Republic
}

\section{ARTICLE INFO}

\section{Article history:}

Received: $19^{\text {th }}$ January 2015

Accepted: $30^{\text {th }}$ August 2015

\section{Keywords:}

baker wheat

emmer

harvest index

phosphorus

scratch plough

weedy species

zinc

\begin{abstract}
$A B S T R A C T$
Triticum dicoccum (emmer) was the main crop from the start of the Neolithic period up to the migration period in central Europe, but almost nothing is known about its planting and nutritive value under prehistoric conditions. To fill this gap, we performed an archaeological experiment aimed at comparing the soil properties, grain and straw yields, hulled and harvest index, nutritive values of grain, glume and straw, plant height, and weedy communities, in stands of T. dicoccum established on an old field used for crop production for several preceding years, and a stand of $T$. dicoccum established on a field converted from permanent grassland by hoe-digging. To demonstrate differences between old and modern technologies and cereals, the obtained data were compared with those for a modern variety of T. aestivum planted on a modern field. Key results and conclusions: (1) digging using a hoe was the easiest way to convert permanent grassland into arable field. The use of a scratch plough or wooden spade for soil preparation was effective only on the permanent arable field without dense grass swards. (2) Broadcast seeding was a simple and effective method for the establishment of T. diccocum stands. Spikelets that remained on the soil surface after seeding were eaten by rodents and birds. (3) Triticum dicoccum possessed a high grain-yield compensation ability, a high competitive ability to cope with weeds, and a high value for its grain, particularly with respect to human $\mathrm{N}, \mathrm{P}, \mathrm{Mg}, \mathrm{Fe}, \mathrm{Cu}$ and $\mathrm{Zn}$ nutrition. (4) In prehistory, no strict borders between arable fields and grasslands probably existed, as many grassland species were also weeds on arable land, such as Plantago lanceolata and Trifolium repens. (5) The grain yield of $T$. dicoccum of $1.7-1.8 \mathrm{tha}^{-1}$ probably corresponds to the yields of prehistoric farmers on high-quality soils in central Europe. The grain yield of a modern variety of T. aestivum was $4.7 \mathrm{t} \mathrm{ha}^{-1}$. (6) The nutritive value of glumes was low in comparison to that of grain. We suppose that prehistoric people preferred food made from clean grain. (7) Grain yield represented 75\% of spikelet yield. (8) The nutritive value of T. dicoccum and T. aestivum straw was insufficient for optimum cattle nutrition, especially due to too low $\mathrm{N}$ and $\mathrm{P}$ concentrations, together with too high fibre and lignin contents. We conclude that straw was used for livestock feeding only if better forage was not available.
\end{abstract}

\section{Introduction}

Triticum dicoccum (emmer wheat) was the most important cereal species planted by the first European farmers, followed by T. monococcum (Tempír 1976; van Zeist et al. 1991; Issac et al. 2010; Kočár, Dreslerová 2010). In archaeological records from the Czech Republic and Germany, the dominance of $T$. dicoccum lasted for at least 6,000 years, from the LBK (Linear Pottery culture, 5,500

*Corresponding author. E-mail: hejcman@fzp.czu.cz
4,900 B.C.) of the Neolithic to the Migration period (A.D. 400-580, Kreuz et al. 2005; Jacomet 2009; Dreslerová, Kočár 2013). In the Czech Republic, cultivation of $T$. dicoccum probably prevailed in lowlands with high-quality soils, whereas cultivation of Hordeum vulgare was more common at higher altitudes in the Late Bronze and Early Iron ages (Dreslerová et al. 2013).

In the Mediterranean region, $T$. dicoccum had been frequently planted up to the High Middle Ages and then only sporadically in low productive and dry regions (Cubero Corpas et al. 2008; Pena-Chocarro, Zapata 2013). In central 
Europe T. dicoccum was a marginal crop during the Middle and New Ages and its planting survived only in low productive and isolated regions up to the twentieth century. The last traditional planting of $T$. dicoccum was recorded in the mountain regions of Slovakia in the second half of the twentieth century (Tempír 1976; Hajnalová, Dreslerová 2010).

Although $T$. dicoccum was one of the most important crops in European Prehistory, almost nothing is known about the nutritive value of its grain, glumes and straw under the conditions produced by prehistoric technology. While some archaeological experiments with the planting of $T$. dicoccum using medieval and prehistoric technologies have been performed, the results of such experiments have usually been restricted to only publication of grain yields (Reynolds 1992; Cubero Corpas et al. 2008; Ehrmann et al. 2014). It is supposed that straw could have been used for the winter feeding of livestock, but the forage quality of $T$. dicoccum straw, and the possible consequences for its use in livestock feeding in prehistory has not, according to the literature, been evaluated. Recently, T. dicoccum has been investigated as an alternative forage crop harvested as green fodder in dry Mediterranean regions with a shortage of high-quality forage (Cazzato et al. 2013). Triticum dicoccum is a hulled (glume) wheat, and post-harvest processing (dehusking) is necessary to obtain clean grain without glumes (Hillman 1984; Peña-Chocarro, Zapata 2003). Did prehistoric people consume clean grain or grain with glumes? To answer this question, a comparison of the nutritive value of glumes and grains is necessary, because the consumption of grain with glumes can affect the nutritional value of the food produced. According to our information, the analysis of the nutritive value of glumes has never been performed, even for $T$. dicoccum planted using modern technology. The nutritive value of plant biomass for human and livestock nutrition can be assessed according to the content of macro- $(\mathrm{N}, \mathrm{P}$, $\mathrm{K}, \mathrm{Ca}$ and $\mathrm{Mg}$ ), micro- (Fe, $\mathrm{Zn}, \mathrm{Cu}$ and $\mathrm{Mn}$ ) and risk $(\mathrm{Cd}$, $\mathrm{Pb}$ ) elements (Hejcman et al. 2010). In addition, the forage quality of livestock fodder can be evaluated according to neutro (NDF) and acid (ADF) detergent fibre and by lignin (ADL) content, which determines the digestibility of organic matter (Hejcmanová et al. 2014).

Broadcast seeding was probably the most frequently used seeding technique in Prehistory, particularly under plough agriculture (Bogaard 2004). According to Reynolds (1992), losses of caryopses, which are normally eaten by birds and rodents from the soil surface, can reach up to $75 \%$ using this technique.

Many current agronomists consider $T$. dicoccum to be prehistoric and therefore, an old-fashioned crop; hence, $T$. dicoccum has not been subjected to intensive modern breeding in contrast to T. aestivum (Zaharieva et al. 2010; Konvalina et al. 2013). Contemporary landraces can therefore be used in archaeological experiments, as their yield potential is considered to be similar to that of landraces in prehistory. In recent years, T. dicoccum has been investigated in particular as an alternative low-yielding cereal that is suitable for marginal areas and organic farming due to its high resistance against disease, low $\mathrm{N}$ and water requirement, and a high competitive ability against weeds in comparison to $T$. aestivum (Marino et al. 2009; 2011; Konvalina et al. 2012a; $2012 \mathrm{~b}$ ). In addition, the grain of T. dicoccum is characterised by higher concentrations of $\mathrm{N}, \mathrm{Fe}$ and $\mathrm{Zn}$ in comparison to T. aestivum; thus T. dicoccum can be used to alleviate human $\mathrm{Zn}$ and Fe deficiency (Suchowilska et al. 2012).

Taking into account the insufficient information on the nutritive value of $T$. dicoccum when planted under prehistoric technology, we decided to perform an experiment. We have selected a region in the northern part of the Czech Republic on chernozem soil, where $T$. dicoccum has been cultivated from the Neolithic to the Migration period (Tempír 1982). The experiment was performed in the openair archaeological museum of Březno near Louny and its scientific aim was to compare soil properties, grain and straw yields, hulled index, nutritive values of grain, glumes and straw, harvest index, plant height. and weedy communities, in stands of $T$. dicoccum established on an old and a new field. The old field was a plot that had been used for crop production for several preceding years (hereafter referred to as "the old field"). The new field was a stand of T. dicoccum established on a field converted from permanent grassland by hoe-digging directly before seeding (hereafter referred to as "the new field"). To demonstrate differences between old and modern technologies and cereals, the data obtained from the experiment with $T$. dicoccum were compared with those of a modern variety of $T$. aestivum planted using modern technology in the neighbourhood of the archaeological experiment (hereafter referred to as "the modern field"). The obtained results are discussed with respect to prehistoric agricultural practices.

\section{Materials and methods}

\subsection{Study site}

The experiment was established at the open-air museum of Březno near Louny in the NW of the Czech Republic $\left(50^{\circ} 21^{\prime} 34.560^{\prime \prime} \mathrm{N}, 1^{\circ} 44^{\prime} 43.621^{\prime \prime} \mathrm{E}\right)$. The museum was established on the right bank of the Ohře (Eger) river in an area of large-scale archaeological excavations performed from the 1950s to the 1970s (Pleinerová, Pavlů 1979; Pleinerová 2000). The area surrounding the museum was densely inhabited from the Neolithic up to the Slavic period (the ninth century A.D.). The altitude of the study site is $190 \mathrm{~m}$ asl, the mean annual temperature is $9^{\circ} \mathrm{C}$, and mean annual precipitation is $470 \mathrm{~mm}$. The area is well known for its highly fertile chernozem soils suitable for the production of high-quality baker's wheat. Weather conditions in the year of planting were favourable for cereal production as there was enough precipitation in the spring.

\subsection{Field experiment}

We established four $2 \times 2 \mathrm{~m}$ experimental plots on the "old field", which had been used for the growing of crops in the 

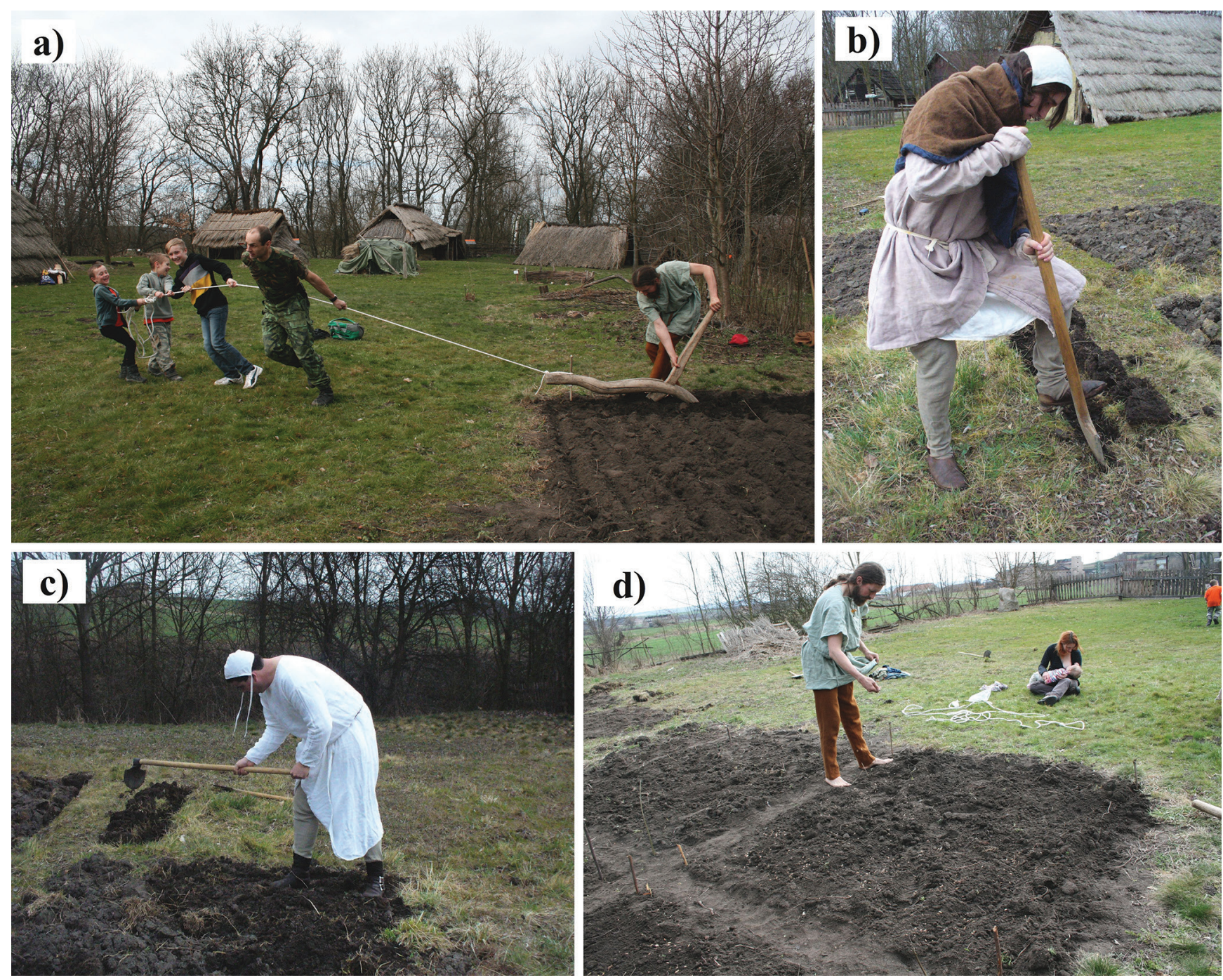

Figure 1. a) Soil preparation by ploughing of the old field, b) soil preparation of the new field (converted from grassland) using a wooden spade, c) soil preparation of the new field using a hoe and d) broadcast seeding of $T$. dicoccum in the old field.

museum for at least ten years before the establishment of our own experiment. The soil was prepared on the day of sowing using a scratch plough (Figure 1a). The depth of ploughing was up to $10 \mathrm{~cm}$. In the close vicinity, another four, $2 \times 2 \mathrm{~m}$ plots as a "new field" were established. They were converted from permanent grassland by the use of a medieval iron hoe. The depth of digging was up to $10 \mathrm{~cm}$ (Figure 1c). Originally, we intended to convert the grassland into arable field by use of a scratch plough and/or a prehistoric or early medieval wooden spade (Figure 1c), but this was too labourintensive and ploughing of the grassland was impossible. The experimental "new" and "old fields" were compared with the "modern field", located at a distance of $60 \mathrm{~m}$ from the experimental plots. The modern field was prepared for seeding by ploughing using modern machinery to a depth of $30 \mathrm{~cm}$.

Broadcast seeding of $T$. dicoccum spikelets onto the new and old fields was performed on $24^{\text {th }}$ April 2014 (Figure 1d). We used the variety Rudico, which is well adapted to Czech conditions (Stehno 2007) and originates from the collection of old landraces collected by the Crop Research Institute, Prague-Ruzyně. The seeding rate was at the upper recommended limit of 400 germinable caryopses per $\mathrm{m}^{2}$ (Stehno 2007). The seeding material was harvested at the Crop Research Institute, Prague-Ruzyně, one year before the establishment of the experiment and the germination of caryopses was $97 \%$. After seeding, the spikelets were harrowed into the soil using iron/wooden rakes. In the modern field, winter wheat, T. aestivum, was seeded in early October 2013, in rows with an inter-row distance of $12.5 \mathrm{~cm}$. We used winter wheat for comparison as this is the most frequently planted wheat form in the Czech Republic under farm conditions. The seeding rate was 300 germinable caryopses per $\mathrm{m}^{2}$. The modern field was under standard conventional farm management and was fertilized by mineral $\mathrm{N}$ at an application rate of $100 \mathrm{~kg} \mathrm{~N} \mathrm{ha}^{-1}$ and pesticides were applied if necessary. The old and new fields did not receive any fertilizer or pesticide application or any mechanical weeding. 

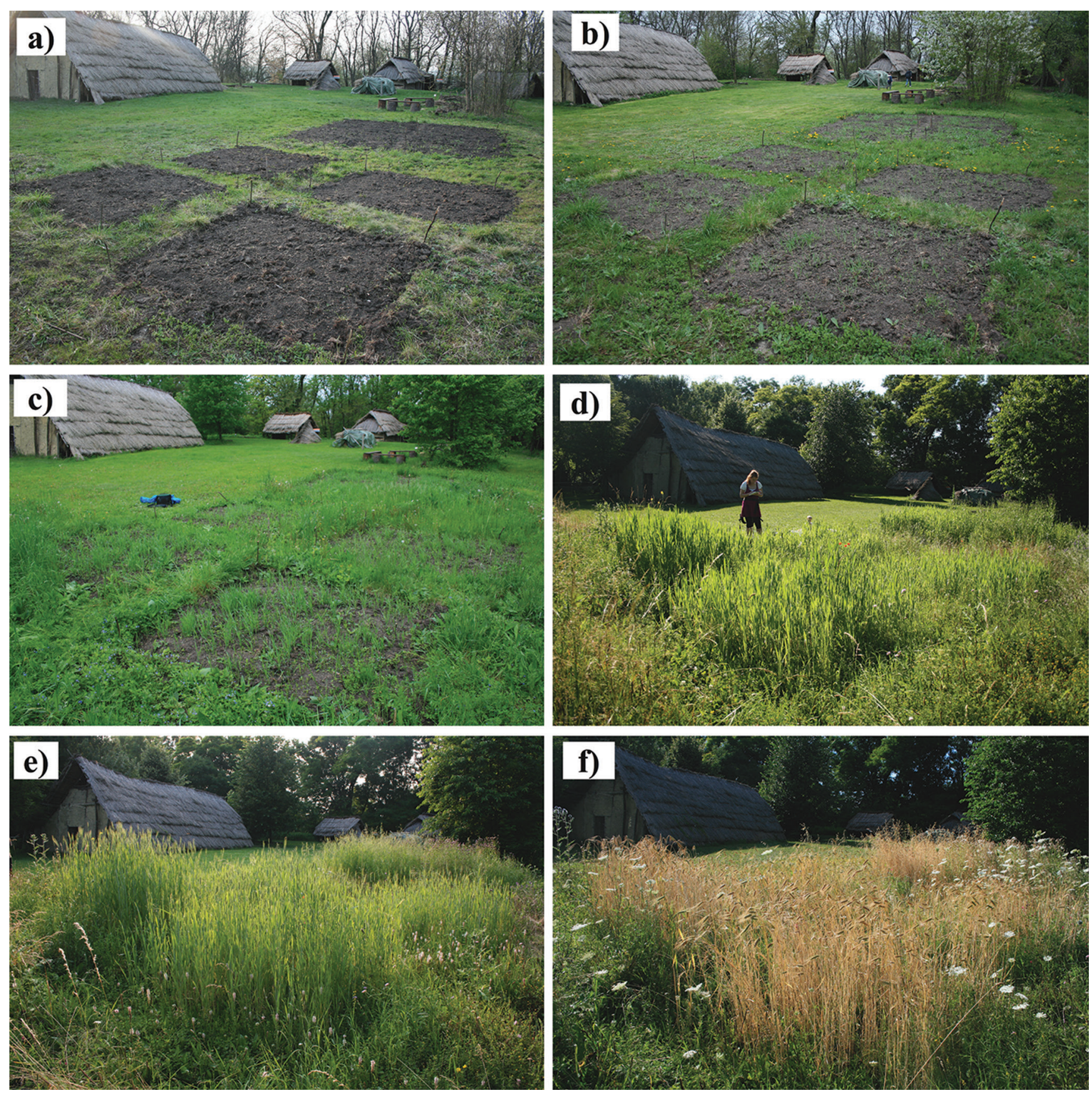

Figure 2. a) New field (four replicates in the foreground) and old field (four replicates in the background) after seeding of $T$. dicoccum on $24^{\text {th }}$ April, b) $28^{\text {th }}$ April, c) $12^{\text {th }}$ May, d) $21^{\text {th }}$ June, e) $6^{\text {th }}$ July and f) $30^{\text {th }}$ July 2013.

\subsection{Soil properties}

The bulk density of the soil was determined at the beginning of July 2013, using soil monoliths collected in metal cylinders $5 \mathrm{~cm}$ tall and $5 \mathrm{~cm}$ in diameter (Kopecký cylinders). Four cylinders were collected per modern, new and old fields, and also for the grassland in the vicinity of the old and new fields. The bulk density was determined after desiccation of the soil monoliths at $60^{\circ} \mathrm{C}$. Five sub-samples of the upper 5 $\mathrm{cm}$ of soil were collected from each plot and mixed into one representative soil sample per plot (four samples per field). In addition, four representative soil samples were collected from the grassland in the close vicinity of the old and new fields.

The soil samples were air-dried, ground in a mortar, and sieved to $2 \mathrm{~mm}$ after the removal of living roots. All analyses were performed at the Eko-Lab, Žamberk (http:// www.ekolab.zamberk.cz), an accredited Czech national laboratory, using Mehlich III extraction to assess plantavailable concentrations of $\mathrm{P}, \mathrm{K}, \mathrm{Ca}, \mathrm{Mg}, \mathrm{Fe}, \mathrm{Zn}, \mathrm{Cu}, \mathrm{Mn}$, $\mathrm{Cd}$ and $\mathrm{Pb}$ (Mehlich 1984). The determination of organic $\mathrm{C}$ content was performed spectrophotometrically after oxidation in a mixture of $\mathrm{K}_{2} \mathrm{Cr}_{2} \mathrm{O}_{7}$ with $\mathrm{H}_{2} \mathrm{SO}_{4}$, at $135^{\circ} \mathrm{C}$. The 

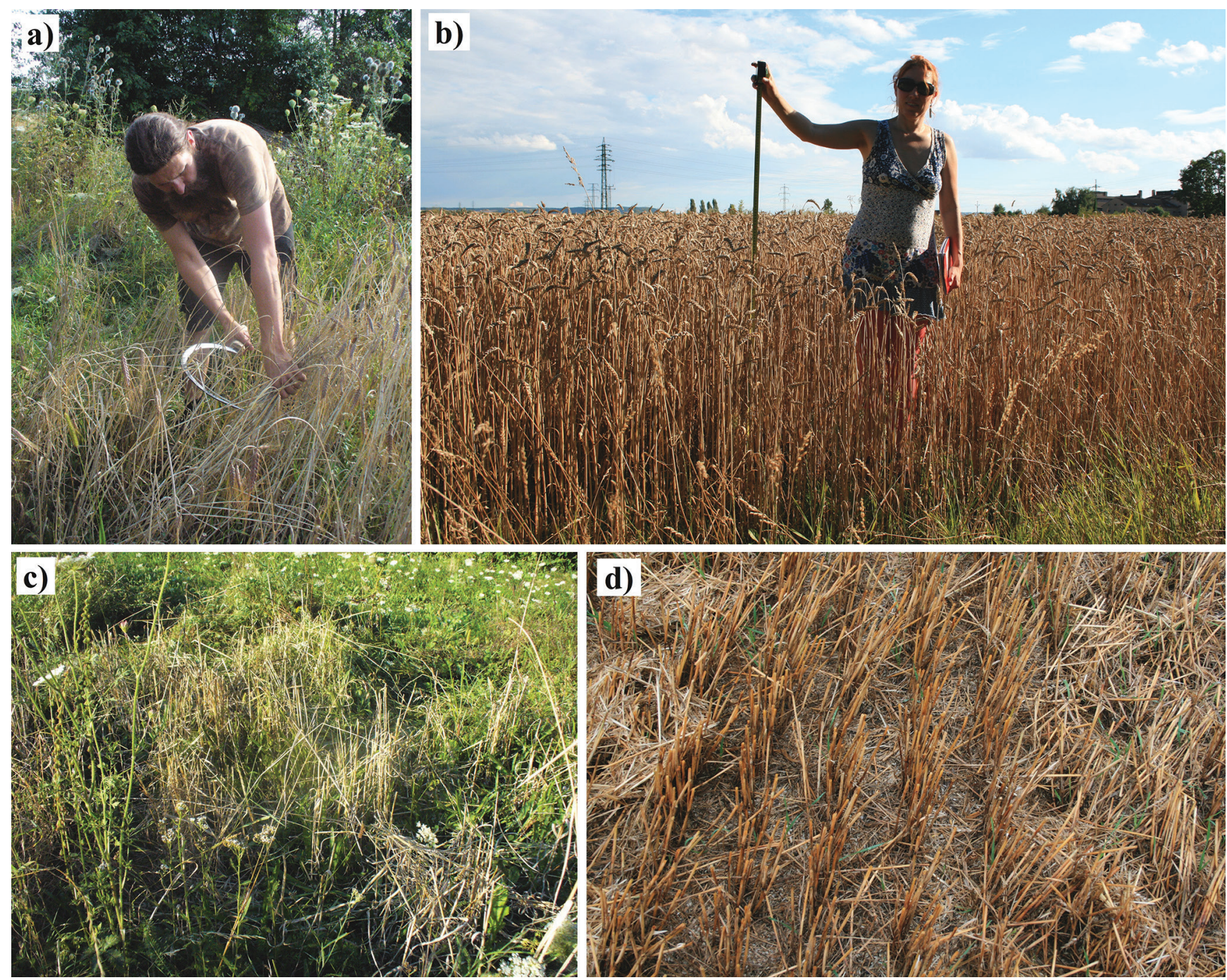

Figure 3. a) Harvesting T. dicoccum in the new field, b) modern field with $T$. aestivum on the day of harvest, c) stubble after harvesting $T$. dicoccum in the new field and d) stubble after harvesting T. aestivum in the modern field.

determination of total $\mathrm{N}$ was performed using a TruSpec $\mathrm{f}$. Leco instrument, where the soil sample was combusted at $950^{\circ} \mathrm{C}$. Soil $\mathrm{pH}\left(\mathrm{H}_{2} \mathrm{O}\right)$ was measured in a suspension of 10 $\mathrm{g}$ dry soil mixed with $50 \mathrm{~mL}$ distilled $\mathrm{H}_{2} \mathrm{O}$. Soil $\mathrm{pH}\left(\mathrm{CaCl}_{2}\right)$ was measured in a 1:5 (w/v) suspension of soil and $0.01 \mathrm{~mol}$ $\mathrm{L}^{-1} \mathrm{CaCl}_{2}$.

\subsection{Yield parameters}

Spikelet density on the soil surface was determined at sowing time just before covering the spikelets by soil, and seedling density two weeks after seeding on $28^{\text {th }}$ April 2013. Harvesting of all plots was performed manually on $10^{\text {th }}$ August 2013. We used an iron sickle and the height of the stubble after harvesting was $5 \mathrm{~cm}$ (Figure 3). Harvested biomass was dried to total desiccation at $60^{\circ} \mathrm{C}$ and spikelets with grain were then divided from the straw (Figure 4). Spikelets were then manually dehusked, and the weight of grain and the hulled index (the proportion of grain weight from whole spikelet weight) was determined. We also counted number of spikes and determined the number of grains per spike by counting. The harvest index was calculated as grain yield divided by straw yield.

\subsection{Weedy vegetation}

The cover of all plant species present in all $2 \times 2 \mathrm{~m}$ plots was estimated directly in percentages at the time of harvest. We counted the number of recorded weedy vascular plant species (species richness) per $4 \mathrm{~m}^{2}$ plot, per $16 \mathrm{~m}^{2}$ and for the whole experiment (see Figure 2 for the whole experiment during the vegetation season) with planting of $T$. diccocum per $32 \mathrm{~m}^{2}$. No weed control was performed in the old and new fields with $T$. dicoccum. In the modern field, herbicides were used to control weeds.

\subsection{Grain, straw and glume chemical properties}

The concentration of macro-elements ( N, P, K, Ca, Mg), micro-elements (Fe, $\mathrm{Zn}, \mathrm{Cu}, \mathrm{Mn}$ ) and risk-elements $(\mathrm{Cd}, \mathrm{Pb})$ were determined in samples of harvested grain, straw and glumes for all treatments. Samples were oven-dried at $60^{\circ} \mathrm{C}$ for $48 \mathrm{~h}$ and were ground into a powder. The $\mathrm{N}$ concentration 

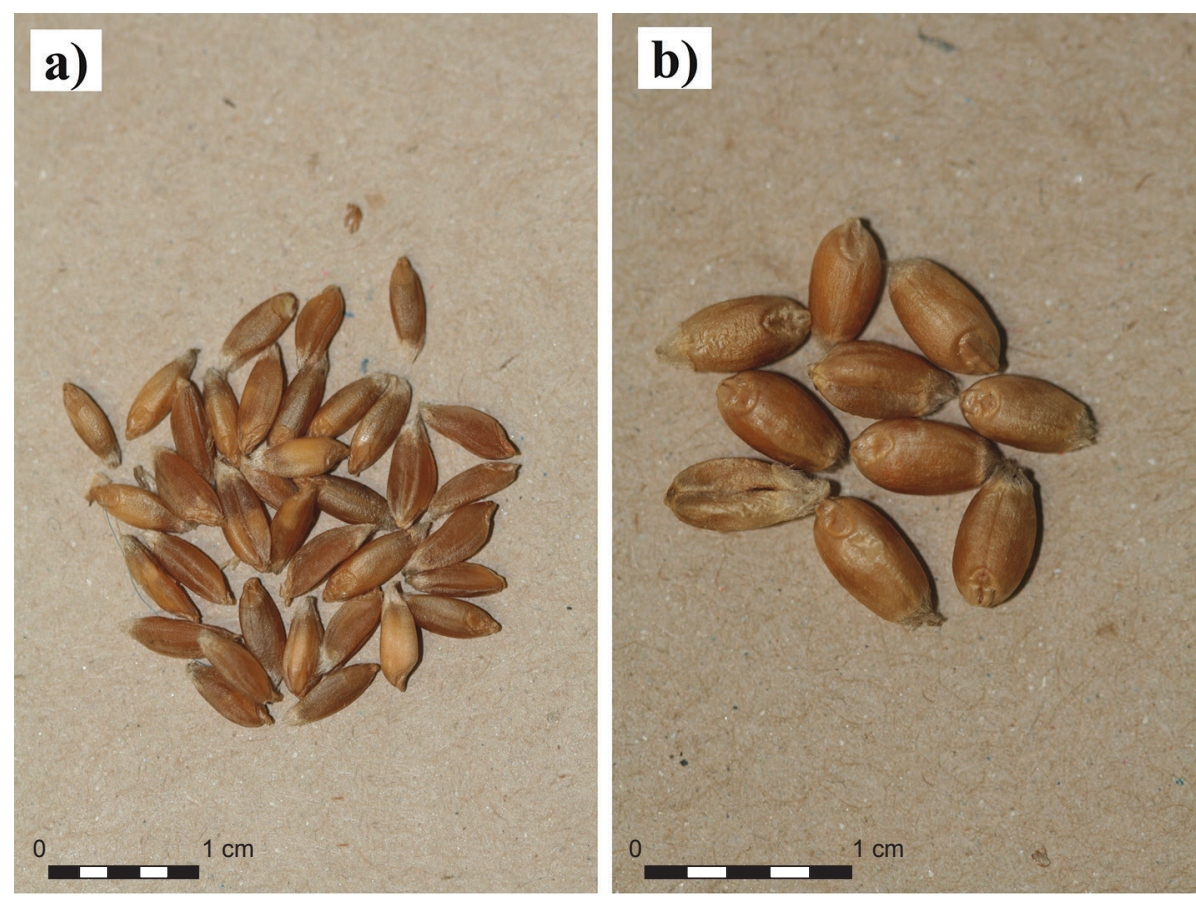

Figure 4. a) Grain of T. dicoccum, b) grain of $T$. aestivum, c) spikelets of $T$. dicoccum and d) glumes of $T$. dicoccum after removal of grains from the spikelets. The size bar in each figure is $1 \mathrm{~cm}$ long.
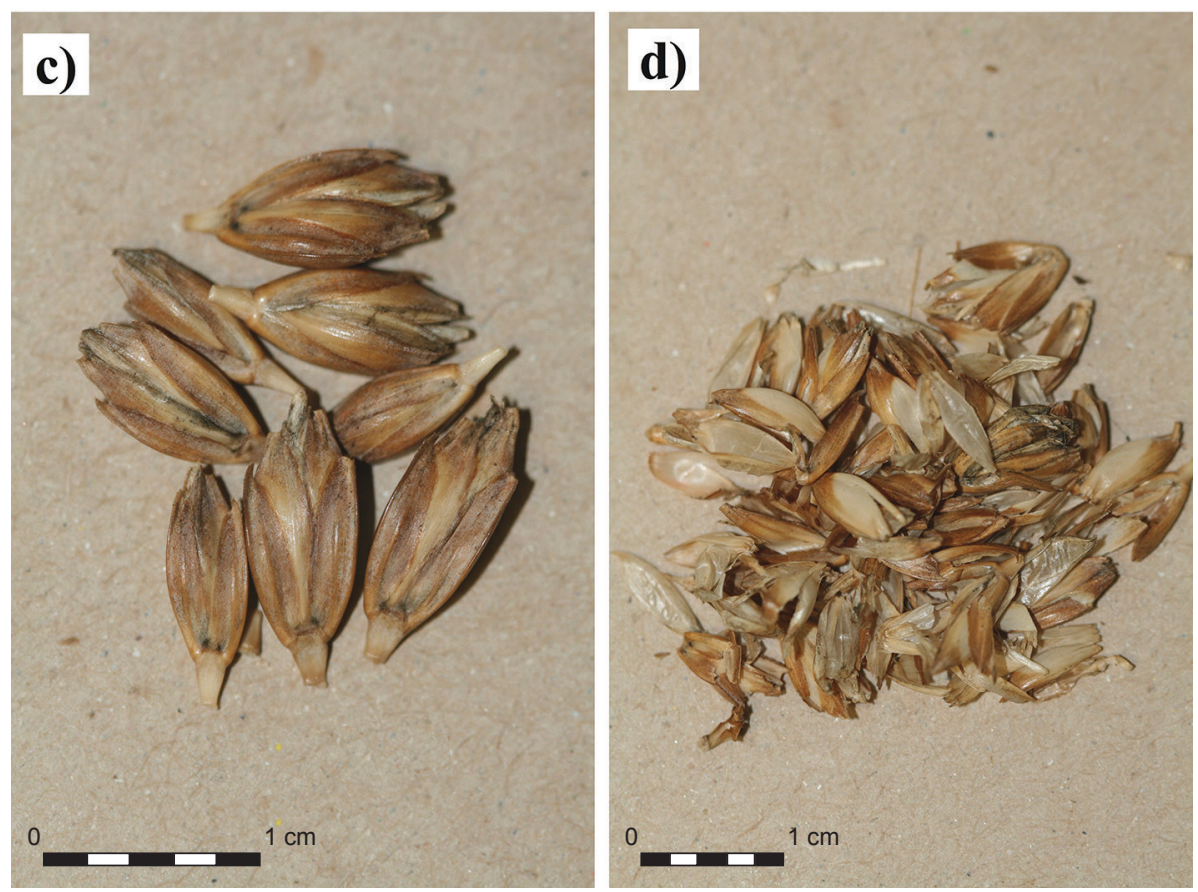

in plant samples was determined using an automated TruSpec (LECO Corporation, USA) analyser by combustion with oxygen in an oven at $950^{\circ} \mathrm{C}$. The combustion products were mixed with oxygen and the mixture was passed through an infrared $\mathrm{CO}_{2}$ detector. Gases in the aliquot circuit were transferred into helium as a carrying gas, conducted through hot copper and converted to $\mathrm{N}$.

To analyse $\mathrm{P}, \mathrm{K}, \mathrm{Ca}, \mathrm{Mg}, \mathrm{Fe}, \mathrm{Zn}, \mathrm{Cu}, \mathrm{Mn}, \mathrm{Cd}$ and $\mathrm{Pb}$, samples were combusted in a microwave oven at $550^{\circ} \mathrm{C}$ and weighed to determine the ash content. Biomass samples were mineralised using aqua regia and element concentrations were then determined in solution using ICP-OES (Varian
VistaPro, Mulgrave, Vic., Australia). Additionally, the contents of neutral- (NDF) and acid- detergent fibre (ADF) and acid detergent lignin (ADL) in straw of T. diccocum from both fields and of $T$. aestivum from the modern field were determined. The NDF represents cellulose, hemi-cellulose and lignin together, and ADF represents cellulose and lignin. The NDF, ADF and ADL contents were determined by standard methods of the Association of Official Analytical Chemists (AOAC 1984).

All analyses were performed at the Eko-Lab Žamberk (http://www.ekolab.zamberk.cz), an accredited Czech national laboratory. 


\subsection{Data analysis}

The obtained data were analysed by one-way ANOVA and in the case of significance, post-hoc comparisons using the Tukey test were performed.

\section{Results}

\subsection{Soil properties}

Out of all the measured soil properties, only soil reaction $\left(\mathrm{pH} / \mathrm{H}_{2} \mathrm{O}\right.$ and $\mathrm{pH} / \mathrm{CaCl}_{2}$ ), the content of organic $\mathrm{C}$ and total $\mathrm{N}$, and the concentrations of plant-available $\mathrm{Zn}, \mathrm{Mn}$ and $\mathrm{Pb}$ differed significantly among treatments (Table 1). Grassland soil differed the most from all other arable soils and was characterised by the lowest $\mathrm{pH}$, the highest content of organic $\mathrm{C}$ and total $\mathrm{N}$, and the highest concentration of plant-available $\mathrm{Zn}$.

\subsection{Yield parameters}

Seedling, grain and spike densities were significantly higher for the old than for the new field (Table 2); however, kernel weight, the number of grains per spike and the harvest index were higher for the new than the old field. The highest grain density and number of grains per spike from all studied treatments were recorded for the modern field with T. aestivum. There were no differences in the hulled index between new and old fields. Grain and straw yields were significantly higher for the modern field with T. aestivum

Table 1. Soil properties in the upper $10-\mathrm{cm}$ layer in new, old and modern fields and in the surrounding grassland. $\mathrm{C}$ org - organic carbon; $\mathrm{N}$ tot - total nitrogen; concentrations of plant-available $\mathrm{P}, \mathrm{K}, \mathrm{Ca}, \mathrm{Mg}, \mathrm{Fe}, \mathrm{Zn}, \mathrm{Cu}, \mathrm{Mn}, \mathrm{Cd}$ and $\mathrm{Pb}$ were determined in Mehlich III solution by ICP-OES.

\begin{tabular}{|c|c|c|c|c|}
\hline & New Field & Old Field & Modern Field & Grassland \\
\hline Soil property & Mean \pm SE & Mean \pm SE & $\mathrm{Mean} \pm \mathrm{SE}$ & Mean \pm SE \\
\hline Bulk density ${ }^{\text {n.s. }}$ & $1.09 \pm 0.06$ & $1.18 \pm 0.07$ & - & $1.24 \pm 0.02$ \\
\hline $\mathrm{pH} / \mathbf{H}_{2} \mathbf{0}^{* *}$ & $8.0 \pm 0.04^{\mathrm{ab}}$ & $8.1 \pm 0.01^{\mathrm{b}}$ & $8.1 \pm 0.03^{b}$ & $7.9 \pm 0.04^{\mathrm{a}}$ \\
\hline $\mathrm{pH} / \mathrm{CaCl}_{2}^{* * *}$ & $7.6 \pm 0.02^{\mathrm{b}}$ & $7.7 \pm 0.01^{\mathrm{bc}}$ & $7.7 \pm 0.02^{\mathrm{c}}$ & $7.5 \pm 0.03^{\mathrm{a}}$ \\
\hline $\operatorname{Corg}\left(\mathrm{g} \mathrm{kg}^{-1}\right)^{* * * *}$ & $17.1 \pm 1.02^{\mathrm{a}}$ & $16.7 \pm 0.12^{\mathrm{a}}$ & $13.8 \pm 1.01^{\mathrm{a}}$ & $23.7 \pm 1.77^{b}$ \\
\hline $\mathbf{N}$ tot $\left.(\mathbf{m g ~ k g})^{-1}\right)^{*}$ & $2.42 \pm 0.26^{\mathrm{ab}}$ & $2.06 \pm 0.05^{\mathrm{ab}}$ & $1.81 \pm 0.13^{\mathrm{a}}$ & $2.60 \pm 0.13^{\mathrm{b}}$ \\
\hline$C: N$ ratio $^{\text {n.s. }}$ & $7.3 \pm 0.70$ & $8.1 \pm 0.18$ & $7.7 \pm 0.52$ & $9.1 \pm 0.46$ \\
\hline$P\left(m g ~ k g^{-1}\right)^{n . s .}$ & $93 \pm 3.7$ & $105 \pm 5.9$ & $111 \pm 26$ & $111 \pm 10$ \\
\hline$\left.K(\mathbf{m g ~ k g})^{-1}\right)^{\text {n.s. }}$ & $488 \pm 36$ & $495 \pm 35$ & $441 \pm 30$ & $506 \pm 59$ \\
\hline $\left.\mathrm{Ca}(\mathrm{mg} \mathrm{kg})^{-1}\right)^{\mathrm{n} . s .}$ & $10392 \pm 312$ & $9493 \pm 242$ & $12039 \pm 2052$ & $9159 \pm 365$ \\
\hline $\operatorname{Mg}\left(m g k^{-1}\right)^{n . s .}$ & $164 \pm 1.8$ & $169 \pm 10$ & $180 \pm 16$ & $164 \pm 9.9$ \\
\hline $\mathrm{Fe}\left(\mathrm{mg} \mathrm{kg}^{-1}\right)^{\mathrm{n} . \mathrm{s} .}$ & $92 \pm 1.4$ & $100 \pm 1.1$ & $105 \pm 7.4$ & $101 \pm 3.9$ \\
\hline $\mathrm{Zn}\left(\mathrm{mg} \mathrm{kg}{ }^{-1}\right)^{*}$ & $8.4 \pm 0.05^{\mathrm{ab}}$ & $8.9 \pm 0.39^{b}$ & $6.3 \pm 0.92^{\mathrm{a}}$ & $9.6 \pm 0.61^{\mathrm{b}}$ \\
\hline $\mathrm{Cu}\left(\mathrm{mg} \mathrm{kg}{ }^{-1}\right)^{\mathrm{n} . \mathrm{s}}$ & $3.9 \pm 0.06$ & $4.1 \pm 0.04$ & $4.2 \pm 0.15$ & $4.0 \pm 0.11$ \\
\hline $\operatorname{Mn}\left(\mathrm{mg} \mathrm{kg}{ }^{-1}\right)^{*}$ & $154 \pm 4.6^{\mathrm{ab}}$ & $187 \pm 7.2^{\mathrm{b}}$ & $134 \pm 18^{\mathrm{a}}$ & $164 \pm 2.9^{\mathrm{ab}}$ \\
\hline Cd (mg kg-1) n.s. & $0.14 \pm 0.004$ & $0.12 \pm 0.003$ & $0.11 \pm 0.002$ & $0.13 \pm 0.021$ \\
\hline Pb $\left(\mathrm{mg} \mathrm{kg}^{-1}\right)^{* * * *}$ & $5.8 \pm 0.07^{\mathrm{c}}$ & $5.9 \pm 0.13^{c}$ & $4.1 \pm 0.17^{\mathrm{a}}$ & $5.2 \pm 0.13^{\mathrm{b}}$ \\
\hline
\end{tabular}

${ }^{*}$ indicates $\mathrm{p}<0.05,{ }^{* *} \mathrm{p}<0.01,{ }^{* * *} \mathrm{p}<0.001$.

Table 2. Seedling and spikelet density of Triticum dicoccum recorded on the soil surface two weeks after seeding on $28^{\text {th }}$ April 2013 , and harvest parameters of T. dicoccum from new and old fields in comparison to T. aestivum from the modern field. Kernel weight - weight of 1,000 caryopses; grain:(grain + glume) ratio - weight proportion of grain from whole spikelet with grains and glumes (hullet index), Harvest index - grain: straw weight ratio, NDL - neutrodetergent fibre, ADF - acid-detergent fibre and ADL - acid-detergent lignin.

\begin{tabular}{|c|c|c|c|}
\hline & New Field & Old Field & Modern Field \\
\hline Harvest parameter & Mean \pm SE & Mean \pm SE & Mean \pm SE \\
\hline Seedling density (per $\left.\mathbf{m}^{2}\right)^{*}$ & $199 \pm 18$ & $365 \pm 52$ & - \\
\hline Spikelet density on soil surface $\left(\text { per } \mathbf{m}^{2}\right)^{\text {n.s. }}$ & $126 \pm 16$ & $90 \pm 10$ & - \\
\hline Kernel weight $(g)^{* * *}$ & $30 \pm 2^{\mathrm{a}}$ & $25 \pm 2^{\mathrm{a}}$ & $48 \pm 1^{b}$ \\
\hline Grain: (grain+glume) ${ }^{\text {n.s. }}$ & $0.75 \pm 0.02$ & $0.76 \pm 0.01$ & - \\
\hline Grain density (per $\left.\mathbf{m}^{2}\right)^{*}$ & $6008 \pm 1067^{\mathrm{a}}$ & $6401 \pm 1242^{\mathrm{a}}$ & $9867 \pm 849^{b}$ \\
\hline Spike density $\left(\text { per } \mathbf{m}^{2}\right)^{* *}$ & $330 \pm 39^{a}$ & $604 \pm 48^{\mathrm{b}}$ & $429 \pm 27^{\mathrm{a}}$ \\
\hline Grains per spike $^{* *}$ & $18 \pm 3^{\mathrm{ab}}$ & $11 \pm 2^{\mathrm{a}}$ & $23 \pm 1^{\mathrm{b}}$ \\
\hline Harvest index ${ }^{*}$ & $0.35 \pm 0.007^{\mathrm{a}}$ & $0.26 \pm 0.03^{\mathrm{b}}$ & $0.33 \pm 0.008^{\mathrm{ab}}$ \\
\hline Straw NDF $\left(\mathrm{g} \mathrm{kg}^{-1}\right)^{\text {n.s. }}$ & $753 \pm 3$ & $708 \pm 12$ & $726 \pm 23$ \\
\hline Straw ADF $\left(\mathrm{g} \mathrm{kg}^{-1}\right)^{\mathrm{n} . s .}$ & $521 \pm 7$ & $476 \pm 12$ & $478 \pm 24$ \\
\hline Straw ADL $\left(\mathrm{g} \mathrm{kg}^{-1}\right)^{\mathrm{n} . \mathrm{s} .}$ & $84 \pm 3$ & $73 \pm 2$ & $79 \pm 9$ \\
\hline
\end{tabular}

" indicates $p<0.05,{ }^{* * *} p<0.01,{ }^{* * * *} p<0.001$. 


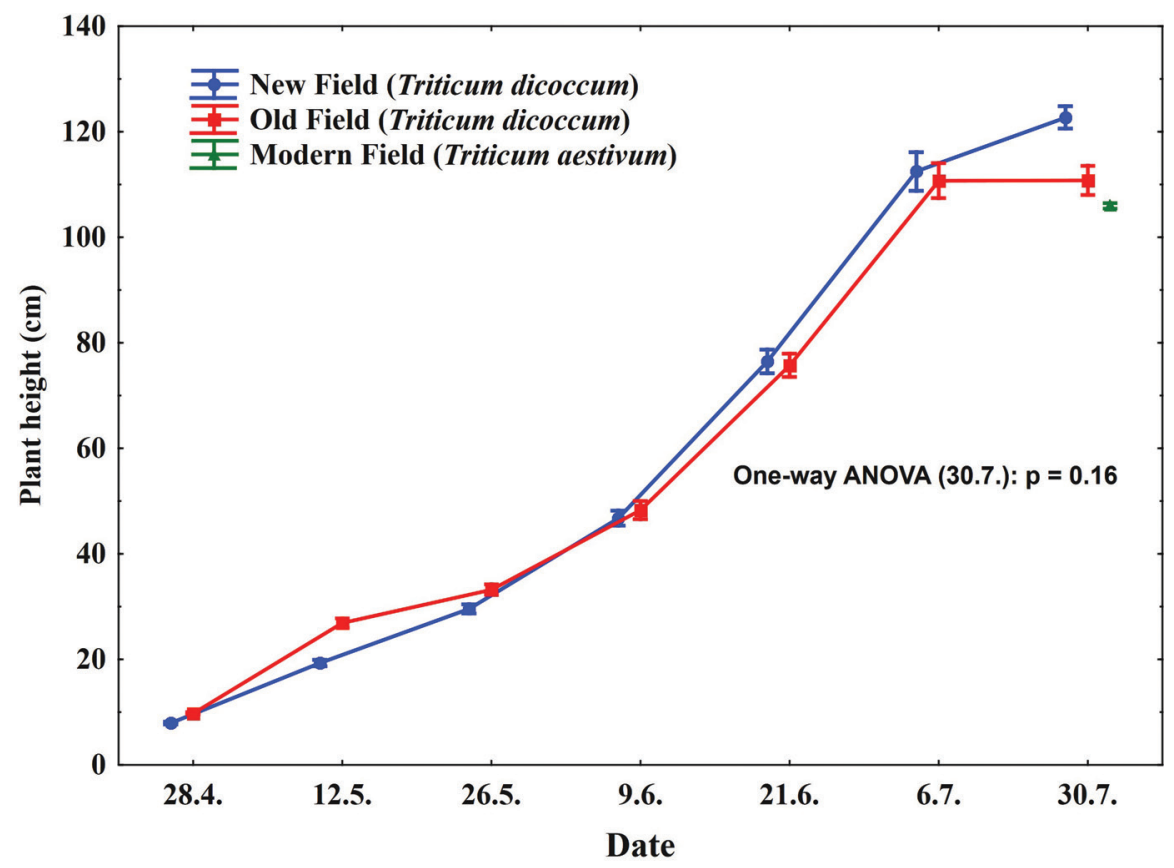

Figure 5. Development of mean plant height of $T$. dicoccum in the new and old fields throughout the vegetation season and the plant height of T. aestivum in the modern field on $30^{\text {th }}$ July 2013. Error bars represent the SE.

than for the new and old fields with $T$. dicoccum (Figure 6a). Mean grain yield was $1.8,1.7$ and $4.7 \mathrm{t} \mathrm{ha}^{-1}$ and mean straw yield was 3.4, 4.5 and $9.4 \mathrm{t} \mathrm{ha}^{-1}$ for the new, old and modern fields, respectively. There were no differences in plant height between new and old fields during the whole experiment (Figure 5). At the end of the experiment on 30 July 2013, mean plant height was $123 \mathrm{~cm}, 111 \mathrm{~cm}$ and $106 \mathrm{~cm}$ in new, old and modern fields, respectively.

\subsection{Weedy vegetation}

No weedy species were recorded in the modern field (see

Figure $3 \mathrm{~d}$ ) and this highly contrasted with 31 and 28 weedy species recorded in the four new $\left(16 \mathrm{~m}^{2}\right.$, see Figure $\left.3 \mathrm{c}\right)$ and four old $\left(16 \mathrm{~m}^{2}\right)$ fields, respectively. In all new and old fields together $\left(32 \mathrm{~m}^{2}\right)$, we recorded 38 weedy species. Species richness per individual plot $\left(4 \mathrm{~m}^{2}\right)$ was significantly higher in new than in old fields (Table 3 ). The total cover of weedy vegetation was 2.4 -fold higher for the new than the old field and this was particularly due to the forbs Plantago lanceolata, P. media and Potentila reptans. Setaria glauca was the main grass weedy species in the new field and Avena fatua, S. glauca and Bromus sterilis in the old field. Lathyrus tuberosus, Medicago lupulina and Trifolium repens were the main legume species recorded in both new and old fields.

Table 3. Cover (mean \pm SE) of weedy species on new and old fields on the day of harvest; 14 August 2013. No weeds were recorded in the modern field.

\begin{tabular}{|c|c|c|}
\hline & New Field & Old Field \\
\hline Harvest parameter & Mean \pm SE & Mean \pm SE \\
\hline Species richness ${ }^{\text {****}}$ & $19 \pm 0.7$ & $14 \pm 0.3$ \\
\hline Total cover $(\%)^{* * * *}$ & $80 \pm 1$ & $33 \pm 9$ \\
\hline Cover of grasses $(\%)^{\text {n.s. }}$ & $12 \pm 6$ & $15 \pm 4$ \\
\hline Avena fatua* & $1 \pm 0.7$ & $7 \pm 2$ \\
\hline Bromus sterilis ${ }^{\text {n.s. }}$ & $0 \pm 0$ & $2.5 \pm 2.5$ \\
\hline Setaria glauca ${ }^{\text {n.s. }}$ & $11 \pm 6$ & $5 \pm 2$ \\
\hline Cover of legumes $(\%)^{\text {n.s. }}$ & $4 \pm 2$ & $3 \pm 1$ \\
\hline Lathyrus tuberosus ${ }^{\text {n.s. }}$ & $2 \pm 1$ & $1.4 \pm 1$ \\
\hline Medicago lupulina $a^{\text {n.s. }}$ & $1.4 \pm 1$ & $0.4 \pm 0.1$ \\
\hline Trifolium repens ${ }^{\text {n.s. }}$ & $0.8 \pm 0.3$ & $0.6 \pm 0.2$ \\
\hline Cover of forbs $(\%)^{* * *}$ & $64 \pm 9$ & $16 \pm 6$ \\
\hline Cirsium arvense $^{\text {n.s. }}$ & $5 \pm 5$ & $11 \pm 7$ \\
\hline Echinops sphaerocephalus ${ }^{\text {n.s. }}$ & $2.5 \pm 2.5$ & $0 \pm 0$ \\
\hline Plantago lanceolata** & $28 \pm 6$ & $0.6 \pm 0.2$ \\
\hline Plantago major $r^{\text {n.s. }}$ & $0.5 \pm 0.2$ & $0.5 \pm 0.3$ \\
\hline Plantago media ${ }^{\text {n.s. }}$ & $10 \pm 7$ & $0 \pm 0$ \\
\hline Potentila reptans $s^{\text {n.s. }}$ & $11 \pm 7$ & $0 \pm 0$ \\
\hline
\end{tabular}

${ }^{*}$ indicates $p<0.05,{ }^{* * *} p<0.01,{ }^{* * *} p<0.001$. 

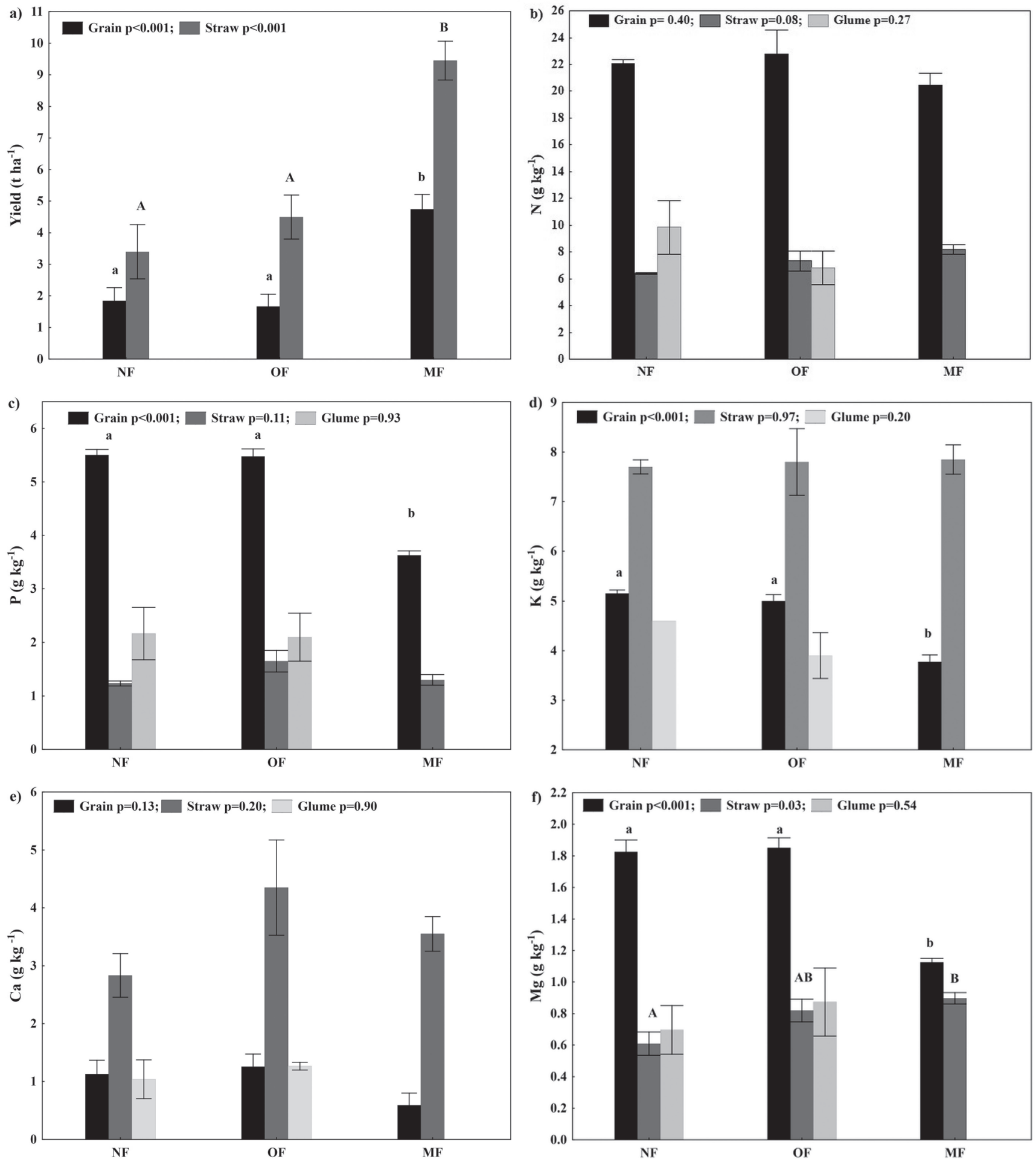

Figure 6. Yield of grain and straw (87\% dry matter content) and concentrations of $\mathrm{N}, \mathrm{P}, \mathrm{K}, \mathrm{Ca}$ and $\mathrm{Mg}$ in grain, straw and glumes (the mean and SE are presented). P - probability value obtained by one-way ANOVA. Treatments with the same letter were not significantly different for the same organ. Multiple comparisons were calculated by the Tukey test for each organ separately.

\subsection{Grain, straw and glumes chemical properties}

The concentrations of $\mathrm{N}, \mathrm{P}, \mathrm{Mg}, \mathrm{Zn}, \mathrm{Cu}$ and $\mathrm{Mn}$ (Mn only in $T$. dicoccum) were higher in grain than in straw and vice versa in the case of $\mathrm{K}, \mathrm{Ca}, \mathrm{Fe}, \mathrm{Cd}$ and $\mathrm{Pb}$. The concentrations of $\mathrm{N}, \mathrm{P}, \mathrm{Mg}, \mathrm{Zn}, \mathrm{Cu}$ and $\mathrm{Mn}$ were similar and those of $\mathrm{Fe}, \mathrm{Cd}$ and $\mathrm{Pb}$ were higher in straw than in glumes of T. dicoccum.
The N, Ca and Cd concentrations in grain, straw and glumes were not significantly affected by treatment. In grain, the mean concentration of $\mathrm{N}$ was $22.0,22.8$ and $20.4 \mathrm{~g} \mathrm{~kg}^{-1}$ in new, old and modern fields, respectively. The mean concentration of $\mathrm{N}$ in straw across all fields was $7.3 \mathrm{~g} \mathrm{~kg}^{-1}$ and the mean concentration of $\mathrm{N}$ in glumes of $T$. dicoccum was $8.3 \mathrm{~g} \mathrm{~kg}^{-1}$. 

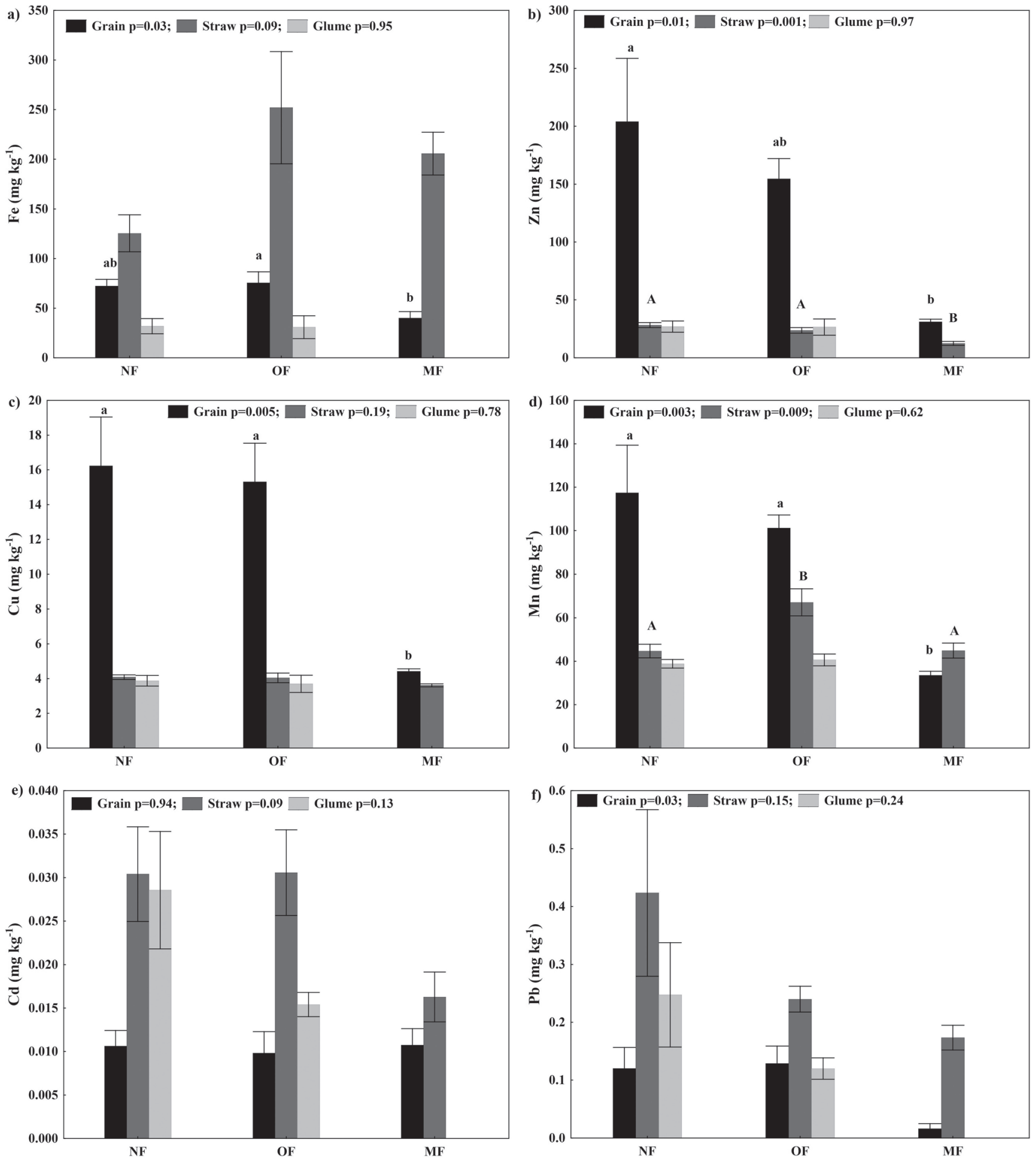

Figure 7. Concentrations of $\mathrm{Fe}, \mathrm{Zn}, \mathrm{Cu}, \mathrm{Mn}, \mathrm{Cd}$ and $\mathrm{Pb}$ in grain, straw and glumes (mean and $\mathrm{SE}$ are presented). $\mathrm{P}$ - probability value obtained by one-way ANOVA. Treatments with the same letter were not significantly different for the same organ. Multiple comparisons were calculated by the Tukey test for the each organ separately.

In grain, the mean concentration of $\mathrm{Ca}$ was $1.1,1.3$ and 0.6 $\mathrm{g} \mathrm{kg}^{-1}$ in new, old and modern fields, respectively. The mean concentration of $\mathrm{Ca}$ in straw across all fields was $3.6 \mathrm{~g} \mathrm{~kg}^{-1}$ and the mean concentration of $\mathrm{Ca}$ in glumes of $T$. dicoccum was $1.2 \mathrm{~g} \mathrm{~kg}^{-1}$.
The concentrations of $\mathrm{P}, \mathrm{K}, \mathrm{Fe}, \mathrm{Zn}, \mathrm{Cu}$ and $\mathrm{Pb}$ in grain of $T$. dicoccum from new and old fields were significantly higher than in grain of T. aestivum from the modern field. There was no effect of treatment on $\mathrm{P}, \mathrm{Fe}, \mathrm{Cu}$ and $\mathrm{Pb}$ concentrations in straw and glumes. The concentrations of $\mathrm{Mg}, \mathrm{Mn}$ and $\mathrm{Zn}$ in 
straw were significantly different among treatments.

In grain, the mean concentration of $\mathrm{P}$ was 5.5 and $3.6 \mathrm{~g}$ $\mathrm{kg}^{-1}$ in $T$. dicoccum and $T$. aestivum, respectively. The mean concentration of $\mathrm{P}$ in straw across all fields was $1.4 \mathrm{~g} \mathrm{~kg}^{-1}$ and the mean P concentration in glumes of $T$. dicoccum was $2.1 \mathrm{~g}$ $\mathrm{kg}^{-1}$. In grain, the mean concentration of $\mathrm{Zn}$ was 204 and 155 $\mathrm{mg} \mathrm{kg}{ }^{-1}$ in $T$. dicoccum in new and old fields and $31 \mathrm{mg} \mathrm{kg}^{-1}$ in T. aestivum in the modern field.

Concentrations of NDF, ADF and ADL in straw were not significantly different among treatments.

\section{Discussion}

\subsection{Soil properties}

Chernozem soils in all treatments were slightly alkaline, with high plant-available $\mathrm{P}, \mathrm{K}, \mathrm{Ca}$ and $\mathrm{Mg}$ concentrations for successful crop production even without any fertilizer input. This indicates the high natural fertility of soils in the study site and probably also explains why the locality has been used for farming activities since Neolithic times. According to our previous experiences from long-term fertilizer experiments (Hejcman et al. 2013a; Hlisnikovský et al. 2014), the concentrations of plant-available $\mathrm{P}, \mathrm{K}, \mathrm{Ca}$ and $\mathrm{Mg}$ in the soil were high enough to not limit crop production. The soil concentration of Mehlich III P ranged from 93 to $111 \mathrm{mg}$ $\mathrm{kg}^{-1}$, whereas in the majority of soils in central Europe, $\mathrm{P}$ concentration is below $50 \mathrm{mg} \mathrm{kg}^{-1}$ and most frequently ranges from 10 to $30 \mathrm{mg} \mathrm{kg}^{-1}$ with no $\mathrm{P}$ fertilizer application (Hejcman etal. 2013b; 2013d; 2014b; Hrevušová et al. 2014). In addition, the $C: N$ ratio was below 10 and this indicates a good mineralisation ability for this soil and $\mathrm{N}$ supply for the crop. Early farmers preferred Chernozem soils in central Europe as they were easily tilled and also highly fertile. In the study site, long-term settlement activities have been documented by large-scale archaeological excavations performed from the 1960s to the 1980s (Pleinerová, Pavlů 1979; Pleinerová 2000). Settlement activities have been linked with the increase in soil $\mathrm{pH}$ and concentrations of plant-available $\mathrm{P}, \mathrm{K}, \mathrm{Ca}, \mathrm{Mg}$ and $\mathrm{Zn}$ in the soil due to the accumulation of wood ash and organic wastes during the life of the settlement (Hejcman et al. 2011). Such an increase in nutrient availability can be detected even one thousand years after abandonment of the settlement and might partly explain the high $\mathrm{P}, \mathrm{Ca}$ and $\mathrm{K}$ concentrations recorded in all our study soils. According to our previous experience, Mehlich III P concentrations can range from 100 to 1,300 $\mathrm{mg} \mathrm{kg}^{-1}$ in former prehistoric and medieval settlements and the presence of a settlement can be identified according to chemical analyses of contemporary arable soil (Hejcman et al. 2011, 2013c). The lowest $\mathrm{pH}$ being in the grassland soil can be explained by acidification of the upper soil layer by rainwater and by the activity of roots. The grassland soil's low $\mathrm{pH}$ was connected with the lowest concentration of plant-available $\mathrm{Ca}$ in our study. On arable land, soil mixing by ploughing decreases the acidification of the upper soil layer. We concluded that differences between all investigated soils were small, without any remarkable effects on wheat production.

\subsection{Yield parameters}

Results from only one year are presented in this paper, because it was impossible to repeat the experiment in other seasons - there was not enough space to establish new fields from grassland, and the modern field was used for other crop species in the farmer's crop rotation. Despite of this handicap, we believe our results to be relevant and highly valuable, grain yields in this year being comparable with other years in our long-term agronomical experiments (unpublished data of authors). The main finding of our study was that $T$. dicoccum is a crop with a very high yield-compensation ability. This is evident from almost the same grain yields being achieved in the new and old fields, despite the highly different yieldforming parameters of the stands. The seedling density was 1.8-fold lower in the new rather than old field, although the seeding rate was the same for both fields. In the new field, a higher proportion of spikelets remained on the soil surface after seeding and harrowing by rakes due to the presence of swards and dense roots from the former grassland, which prevented the covering of spikelets by fine-structured soil during harrowing. As we recorded, spikelets that remained on the soil surface did not germinate, as they were eaten by birds and rodents. Together with the poorer germination and emergence of seedlings due to bad seed beds in the new field, this was responsible for the lower density of seedlings. This lower seedling density was connected with a 1.80 -fold lower density of spikes, but only with a 1.07-fold lower density of grains in the new field compared with the old. Minimal differences in grain density were given by the 1.64-fold greater number of grains per spike in the new rather than old field. In addition, kernel weight was 1.20-fold higher in the new rather than old field. In the new field, plants also invested a higher proportion of energy into grain compared with the old field, due to the higher harvest index. The result of this high grain-yield compensation ability was that there was almost the same grain yield in both the new and old fields, despite the different characteristics of the stands. We believe that this high grain-yield compensation ability is probably the reason why $T$. dicoccum was such a successful and widespread cereal species during prehistory, despite its relatively low grain yields in comparison to T. aestivum. A high grain-yield compensation ability was probably responsible for a relatively high inter-annual grain-yield stability, which was probably more important for prehistoric farmers than obtaining high grain yields per area. In addition, planting of T. diccocum was very simple and the possible mistakes made by farmers during soil preparation and seeding, or problems with seedling emergence because of unfavourable weather conditions, were subsequently compensated for during the tillering, flowering and grain-filling periods.

The mean grain yield for $T$. dicoccum of 1.7-1.8 $\mathrm{t} \mathrm{ha}^{-1}$ recorded in our experiment is lower than commonly recorded yields by other authors in central Europe using modern agricultural technology (1.8-3.3 $\mathrm{t} \mathrm{ha}^{-1}$, see De Vita et al. 
2006; Konvalina et al. 2012a; 2012b). Higher grain yields resulting from the use of modern technology are ensured through better establishment of the stand, better control of weeds, and better $\mathrm{N}$ nutrition of plants. We believe that grain yields in our experiment are consistent with those obtained by prehistoric farmers using no fertilizer input on highly productive Chernozem soils in central Europe. Such yields were probably much higher than on dry Mediterranean or low fertile soils in other European regions where common grain yields of $T$. dicoccum without any fertilizer input range from approximately 0.5 to $1.5 \mathrm{t} \mathrm{ha}^{-1}$ (Marino et al. 2009; 2011). The higher grain yield of $T$. aestivum compared to $T$. dicoccum was a result of the higher kernel weight, grain density and number of grains per spike. The grain yield of $4.7 \mathrm{t} \mathrm{ha}^{-1}$ was lower than common grain yields achieved by modern varieties of T. aestivum on the most productive soils in the Czech Republic, which range from approximately 6 to $11 \mathrm{t} \mathrm{ha}^{-1}$ (Kunzová, Hejcman 2009; 2010; Hejcman et al. 2012). The possible explanation for this is the unusually low harvest index (0.33) and the tall plants, which are typical for T. dicoccum (see Konvalina et al. 2012b) rather than for modern varieties of T. aestivum. This can be explained by the extraordinarily wet spring in the study year, which prevented the application of growth regulators for the shortening of stems. High grain yields of modern short-straw varieties of $T$. aestivum are particularly reflected in their high harvest index, which usually ranges from 0.5 to 0.6 (Stehno et al. 2008).

The kernel weight of 1,000 caryopsis of T. dicoccum in our experiment ( 25 and $30 \mathrm{~g}$ ) was lower than that reported by other authors: $32-41 \mathrm{~g}$ with a mean value $39 \mathrm{~g}$ by De Vita et al. (2006); $31 \mathrm{~g}$ by Konvalina et al. (2012b); $34 \mathrm{~g}$ by Konvalina et al. (2012c) and 47-51 g with a mean value $48 \mathrm{~g}$ by Marino et al. (2011). The lower values recorded in our experiment can be explained by the high density of spikes, the competition with weedy species, and there being insufficient $\mathrm{N}$ nutrition in the grain-filling period. The hulled index of $0.75-0.76$ recorded in this study was similar to values reported by other authors: 0.76 by Konvalina et al. (2012b) and $0.62-0.75$ by Marino et al. $(2009,2011)$. This indicates that the grain yield of $T$. dicoccum is at least about $25 \%$ lower than the spikelet yield. According to the findings of Konvalina et al. (2012c), real grain yield after mechanical dehusking represents $50-60 \%$ of the spikelet yield.

\subsection{Weedy vegetation}

The next finding of this study was that probably no strict borders between arable fields and grasslands existed in prehistory. A further reason why prehistoric farmers preferred $T$. dicoccum was its high competition ability and therefore tolerance to weeds. This was particularly due to plant heights being above $100 \mathrm{~cm}$. A high tolerance to weeds is one of the reasons why T. dicoccum is a recommended crop for contemporary organic farms, where no herbicides can be applied (Šrámek et al. 2011). In the new field, the cover of weedy species was so high that after harvest, the stubble appeared similar to the grassland that could be immediately grazed by livestock. Grassland species regenerated predominantly from those swards not completely destroyed by digging. In the old field, the stubble was also rich in the biomass of green weedy species, enabling immediate livestock grazing. Both fields were full of plant species that are considered typical grassland species today. For example, pollen of Plantago lanceolata in sediments is considered as an indicator of grasslands in the landscape, but this species was the main weedy species in the new field and was present also in the old field. We believe that the pollen of this species in sediments is therefore rather an indicator of 'non-forest vegetation, arable fields and grasslands' together. Our results support the conclusion by Brun (2011) that pollen of $P$. lanceolata in sediments indicates not only grasslands, but also cultivated fields in the prehistoric period. However, not all weedy species are detrimental to the crop yield; legumes fix $\mathrm{N}_{2}$ and thus increase $\mathrm{N}$ availability for the crop and can thus increase grain yield. A decrease in $\mathrm{N}$ availability in the soil under high $\mathrm{P}$ and $\mathrm{K}$ supply increases their competitive ability (Pavlů et al. 2012). For example, Lathyrus tuberosus, the main legume weedy species in our experiment, was also the main weedy species in plots with planting of cereals under no $\mathrm{N}$ fertilizer input over the last 100 years in the experiment on Chernozem soil close to Vienna (R. W. Neugschwandtner, leader of the experiment, pers. comm.). Nitrogen fixed by Lathyrus improved grain yield in this experiment. Legumes are thus beneficial for cereal production and we think that L. tuberosus and Trifolium repens could be common weedy species in prehistoric fields. Trifolium repens is also a highquality forage species that is well-adapted to grazing and might be spread via endozoochory by grazing livestock, as its seeds survives passage through the digestive tract (Hejcman et al. 2013e).

We conclude that, in contrast to modern fields with no weeds, prehistoric fields provided two benefits: the main crop yield, and also forage for livestock after harvesting the main crop.

\subsection{Grain, straw and glume chemical properties}

The next finding of this study was that the nutritive value of T. dicoccum grain was higher than that of T. aestivum and that food prepared from the grain of $T$. dicoccum better fulfilled the nutritional requirements of humans than food from the grain of T. aestivum. This is particularly due to the higher $\mathrm{P}$, $\mathrm{Mg}, \mathrm{Cu}, \mathrm{Zn}$ and $\mathrm{Fe}$ concentrations. High $\mathrm{P}, \mathrm{Cu}, \mathrm{Fe}$ and $\mathrm{Zn}$ concentrations in grain were cardinally important, especially for poor people with no or limited access to meat, which is generally a better source of easily available $\mathrm{P}, \mathrm{Cu}, \mathrm{Fe}$ and $\mathrm{Zn}$ than grain, where a high proportion of minerals can be fixed into phytate, which is indigestible for humans (Kumar et al. 2010). Phosphorus is necessary for adequate growth, as $90 \%$ of $\mathrm{P}$ in the human body is fixed into bones in the form of hydroxy apatite (Wyant et al. 2013). Therefore, children have higher $\mathrm{P}$ requirements than adults for the development of the skeleton, and pregnant and lactating women also have increased $\mathrm{P}$ requirements in comparison to adult men. The next important element is $\mathrm{Zn}$; if the human diet is based on 
cereals, the concentration of $\mathrm{Zn}$ in grain must exceed 50 $\mathrm{mg} \mathrm{kg}^{-1}$ to fully cover the $\mathrm{Zn}$ nutritional requirements (Zou et al. 2012). In contrast to the sub-optimal concentration of $\mathrm{Zn}$ in grain of T. aestivum, the concentration of $\mathrm{Zn}$ in grain of $T$. dicoccum was three to four times above this limit. Higher concentrations of $\mathrm{P}, \mathrm{Mg}, \mathrm{Cu}, \mathrm{Zn}$ and $\mathrm{Fe}$ in grain of $T$. dicoccum than in grain of T. aestivum agree with the results of Suchowilska et al. (2012) and indicate a high nutritive value for grain of $T$. dicoccum. Although there was no $\mathrm{N}$ fertilizer application in the new and old fields in contrast to the modern field, the $\mathrm{N}$ concentration (and therefore the protein content) in the grain of T. dicoccum was slightly higher than that in the T. aestivum grain. The next characteristic feature of $T$. dicoccum is thus the high protein content in its grain and therefore, its high nutritional value even without any $\mathrm{N}$ fertilizer application (De Vita et al. 2006; Giacintucci et al. 2014). The nutritive value of grain can be decreased by concentrations of high-risk elements. We recorded higher $\mathrm{Pb}$ concentrations in the T. dicoccum grain than in the T. aestivum grain, probably because higher plant-available $\mathrm{Pb}$ concentrations were present in the new and old fields compared to the modern field. In addition, lower $\mathrm{Pb}$ concentrations in the grain of T. aestivum can be the result of a dilution effect - a higher grain yield is frequently connected with lower (diluted) concentrations of many other elements. Concentrations of $\mathrm{Pb}$ and $\mathrm{Cd}$ in the grain in our study were below the toxic level for human nutrition and were consistent with $\mathrm{Pb}$ and $\mathrm{Cd}$ concentrations recorded in grain of cereals in the Czech Republic (Kroutil et al. 2010; Hejcman et al. 2013a).

It is highly probable that $T$. dicoccum was a highly popular crop in prehistory due also to the higher nutritive value of its grain compared to that of T. aestivum. In any estimation of the nutritional status of prehistoric human populations, the chemical composition of prehistoric crops must also be taken into account, because this composition can be highly different to that of more recent crops, as demonstrated in this study.

A further question was whether people prepared food from clean grain or from whole spikelets, i.e. grain and glumes together. The nutritive value of glumes and spikelets was similar to that of straw, and both nutritive values were substantially lower than that of grain. This is clear from the $\mathrm{N}, \mathrm{P}, \mathrm{Mg}, \mathrm{Fe}, \mathrm{Cu}$ and $\mathrm{Zn}$ concentrations that are too low for optimum human nutrition. We therefore infer that the prehistoric population clearly preferred food prepared from clean grain, and that from whole spikelets was probably eaten only in critical times of food shortage.

It is also frequently presumed that the straw of prehistoric cereals was used to feed livestock. The nutritive value of T. dicoccum and T. aestivum straw was similarly low. The concentrations of $\mathrm{N}$ and $\mathrm{P}$ were especially low and were insufficient for optimum cattle nutrition; in forage, the optimum $\mathrm{N}$ and $\mathrm{P}$ concentrations for cattle nutrition range from 19 to 26 and from 2.3 to $3.7 \mathrm{~g} \mathrm{~kg}^{-1}$, respectively, which can be found in young grassland biomass and in high-quality meadow hay (Hejcman et al. 2014a). The content of the fibre fractions (NDF, ADF) and lignin (ADL) in straw of both species was too high for optimum cattle nutrition, for which the content of NDF, ADF and ADL ranges from 330 to 450 , from 190 to 300 . and up to $80 \mathrm{~g} \mathrm{~kg}^{-1}$, respectively. We suppose that straw was used for livestock feeding probably only if better forage was not available during the winter. Straw enabled livestock to survive the winter, but without any live-weight gain or sufficiently high milk production. It is possible to suppose that straw left on the harvested fields was commonly used for the winter feeding of livestock from the Neolithic period up to the start of hay making in the Hallstatt period in central Europe (ca. 600 B.C., Hejcman et al. 2013e), since no better sources of forage, with the exception of leaf fodder from Ulmus, Fraxinus and Tilia (Hejcmanová et al. 2014), were available.

\section{Conclusions}

Archaeological experiments can help to understand why particular crops were popular in the past, and how they were planted and/or used for food production. We summarise our experience with planting T. diccocum using prehistoric (scratch plough) and medieval (iron hoe) technology under the following points:

Digging by iron hoe was the easiest way to convert permanent grassland into arable field. The use of a scratch plough or wooden spade for soil preparation was effective only in the permanent arable field without dense grass swards.

Broadcast seeding was a simple and effective method for the establishment of the T. diccocum stand. Spikelets that remained on the soil surface after seeding were lost, as they were eaten by rodents and birds.

Triticum dicoccum demonstrates high grain-yield compensation ability, high stability of grain production, high competitive ability to cope with weeds, and high nutritive value of the grain, particularly with respect to $\mathrm{N}, \mathrm{P}, \mathrm{Mg}, \mathrm{Fe}$, $\mathrm{Cu}$ and $\mathrm{Zn}$ for the human diet. These characteristics were probably reasons for the popularity of this crop during prehistory.

In prehistory, no strict borders between arable fields and grasslands probably existed. Many species that are considered as grassland species today (e.g. Plantago lanceolata and Trifolium repens), were probably also weeds in prehistoric fields. Weedy vegetation was probably a valuable source of forage for livestock after the harvesting of cereals.

The grain yield of $T$. dicoccum of 1.7-1.8 $\mathrm{tha}^{-1}$ recorded in our experiment probably corresponds with the yields of prehistoric farmers on high-quality soils in central Europe. The grain yield of a modern variety of T. aestivum produced by the use of modern agricultural technology was $4.7 \mathrm{tha}^{-1}$.

The nutritive value of glumes is low compared to that of grain. We conclude that prehistoric people most probably preferred food prepared from dehusked grain and that food using whole spikelets was probably eaten only in critical times of food shortage. Grain yield represented $75 \%$ of spikelet yield. 
The nutritive value of $T$. dicoccum and T. aestivum straw is insufficient for optimal cattle nutrition, especially due to their low $\mathrm{N}$ and $\mathrm{P}$ concentrations, together with excessively high fibre and lignin contents. We conclude that straw was only used to feed livestock in combination with other fodder, or if better forage was not available.

\section{Acknowledgements}

We gratefully acknowledge Pavel Šroubek and Richard Rosenberg for their assistance with field work and Michal Jun., Jan, Jaroslav and Amálie Hejcman for their assistance with data collection. This paper is dedicated to Bedřich Štauber (deceased in October 2013), the director of the regional museum in Louny, who allowed us to perform the research in the open-air museum. The research was supported by project NAZV QJ1210211 and by project UHK-FF.

\section{References}

AOAC 1984: Official Methods of Analysis. $14^{\text {th }}$ edition. Washington, DC: Association of Official Analytical Chemists.

BEHRE, K. E., WASYLIKOWA, K., van ZEIST, W. (Eds.) 1991: Progress in Old World Palaeoethnobotany. CRC Press.

BOGAARD, A. 2004: Neolithic farming in Central Europe. Routledge.

BRUN, C. 2011: Anthropogenic indicators in pollen diagrams in eastern France: a critical review. Vegetation History and Archaeobotany 20, $135-142$.

CAZZATO, E., TUFARELli, V., LAUDADiO, V., STELlACCI, A. M., SELVAGGI, M., LEONI, B., TROCCOLI, C. 2013: Forage yield and quality of emmer (Triticum dicoccum Schubler) and spelt (Triticum spelta L.) as affected by harvest period and nitrogen fertilization. Agriculturae Scandinavica, Section B-Soil \& Plant Science 63, 571-578.

CUBERO CORPAS, C., CASTANYER, I. O. I., ESPONA, M. D. I., SUBIRANA, M. O. I. 2008: From the granary to the field; archaeobotany and experimental archaeology at 1'Esquerda (Catalonia, Spain). Vegetation History and Archaeobotany 17, 85-92.

DE VITA, P., RIEFOLO, C., CODIANNI, P., CATTIVELLI, L., FARES, C. 2006: Agronomic and qualitative traits of T. turgidum ssp. dicoccum genotypes cultivated in Italy. Euphytica 150, 195-205.

DRESLEROVÁ, D., KOČÁR, P. 2013: Trends in cereal cultivation in the Czech Republic from the Neolithic to the Migration period (5500 B. C. A. D. 580). Vegetation History and Archaeobotany 22, 257-268.

DRESLEROVÁ, D., KOČÁR, P., CHUMAN, T., ŠEFRNA, L., PONIŠTIAK, Š. 2013: Variety in cereal cultivation in the Late Bronze and Early Iron Ages in relation to environmental conditions. Journal of Archaeological Science 40,1988-2000.

EHRMANN, O., BIESTER, H., BOGENRIEDER, A., RÖSCH, M. 2014: Fifteen years of the Forchtenberg experiment - results and implications for the understanding of Neolithic land use. Vegetation History and Archaeobotany 23, 5-18.

GIACINTUCCI, V., GUARDEŇO, L., PUIG, A., HERNANDO, I., SACCHETTI, G., PITTIA, P. 2014: Composition, protein contents, and microstructural characterisation of grains and flours of emmer wheats (Triticum turgidum ssp. dicoccum) of the Central Italy type. Czech Journal of Food Science 32, 115-121.

HAJNALOVÁ, M., DRESLEROVÁ, D. 2010: Ethnobotany of einkorn and emmer in Romania and Slovakia: towards interpretation of archaeological evidence. Památky Archeologické 101, 169-202.

HEJCMAN, M., SZÁKOVÁ, J., SCHELLBERG, J., TLUSTOŠ, P. 2010 : The Rengen Grassland experiment: relationship between soil and biomass chemical properties, amount of elements applied, and their uptake. Plant and Soil 333, 163-179.
HEJCMAN, M., ONDRÁČEK, J., SMRŽ, Z. 2011: Ancient waste pits with wood ash irreversibly increase crop production in Central Europe. Plant and Soil 339, 341-350.

HEJCMAN, M., KUNZOVÁ, E., ŠREK, P. 2012: Sustainability of winter wheat production over 50 years of crop rotation and N, P and K fertilizer application on illimerized luvisol in the Czech Republic. Field Crops Research 139, 30-38.

HEJCMAN, M., BERKOVÁ, M., KUNZOVÁ, E. 2013a: Effect of longterm fertilizer application on concentrations of elements $(\mathrm{N}, \mathrm{P}, \mathrm{K}, \mathrm{Ca}, \mathrm{Mg}$, $\mathrm{As}, \mathrm{Cd}, \mathrm{Cu}, \mathrm{Cr}, \mathrm{Fe}, \mathrm{Mn}, \mathrm{Ni}, \mathrm{Pb}, \mathrm{Zn}$ ) in grain of spring barley. Plant, Soil and Environment 59, 329-334.

HEJCMAN, M., HEJCMANOVÁ, P., PAVLU゚, V., BENEŠ, J. 2013e: Origin and history of grasslands in Central Europe - a review. Grass and Forage Science 68, 345-363.

HEJCMAN, M., KARLÍK, P., ONDRÁČEK, J., KLÍR, T. 2013d: Shortterm Medieval settlement activities irreversibly changed forest soils and vegetation in Central Europe. Ecosystems 16, 652-663.

HEJCMAN, M., SOUČKOVÁ, K., GOJDA, M. 2013c: Prehistoric settlement activities changed soil $\mathrm{pH}$, nutrient availability, and growth of contemporary crops in Central Europe. Plant and Soil 369, 131-140.

HEJCMAN, M., SOUČKOVÁ, K., KRISTUF, P., PEŠKA, J. 2013b: What questions can be answered by chemical analysis of recent and paleosols from the Bell Beaker barrow (2500-2200 BC) in Central Moravia, the Czech Republic? Quaternary International 316, 179-189.

HEJCMAN, M., HEJCMANOVÁ, P., STEJSKAlOVÁ, M., PAVLŮ, V. 2014a: Nutritive value of winter collected annual twigs of main European woody species, mistletoe and ivy and its possible consequences for winter foddering of livestock in prehistory. The Holocene 24, 659-667.

HEJCMAN, M., SOCHOROVÁ, L., PAVLŮ, V., STROBACH, J., DIEPOLDER, M., SCHELLBERG, J. 2014b: The Steinach Grassland Experiment: soil chemical properties, sward height and plant species composition in three cut alluvial meadow after decades-long fertilizer application. Agriculture, Ecosystems and Environment 184, 76-87.

HEJCMANOVÁ, P., STEJSKALOVÁ, M., HEJCMAN, M. 2014: Forage quality of leaf-fodder from main broad-leaved woody species and its possible consequences for the Holocene development of forest vegetation in Central Europe. Vegetation History and Archaeobotany 23, 607-613.

HILLMAN, G. C. 1984: Traditional husbandry and processing of archaic cereals in modern times. Part I, the glume-wheats. Bulletin on Sumerian Agriculture 1, 114-152.

HLISNIKOVSKÝ, L., KUNZOVÁ, E., HEJCMAN, M., DVOŘÁČEK, V. 2015: Effect of fertilizer application, soil type, and year on yield and technological parameters of winter wheat (Triticum aestivum) in the Czech Republic. Archives in Agronomy and Soil Science 61, 33-53.

HREVUŠOVÁ, Z., HEJCMAN, M., HAKL, J., MRKVIČKA, J. 2014: Soil chemical properties, plant species composition, herbage quality, production and nutrient uptake of an alluvial meadow after 45 years of $\mathrm{N}$, P and K application. Grass and Forage Science DOI: 10.1111/gfs.12112.

ISSAC, A. D., MULDOON, M., BROWN, K. A., BROWN, T. A. 2010: Genetic analysis of wheat landraces enables the location of the first agricultural sites in Italy to be identified. Journal of Archaeological Science 37, 950-956.

JACOMET, S. 2009: Plant economy and village life in Neolithic lake dwellings at the time of the Alpine Iceman. Vegetation History and Archaeobotany 18, 47-59.

KOČÁR, P., DRESLEROVÁ, D. 2010: Archaeobotanical finds of cultivated plants in the prehistory of the Czech Republic. Pamatky Archeologicke 101, 203-242.

KONVALINA, P., CAPOUCHOVÁ, I., STEHNO, Z. 2012a: Agronomically important traits of emmer wheat. Plant, Soil and Environment 58, 341346.

KONVALINA, P., CAPOUCHOVÁ, I., STEHNO, Z., KÁS̆, M., JANOVSKÁ, D., ŠKEŘÍKOVÁ, A., MOUDRÝ, J. 2012c: Pěstováni a využití pšenice dvouzrnky v ekologickém zemědělství. Výzkumný ústav rostlinné výroby, Prague.

KONVALINA, P., CAPOUCHOVÁ, I., STEHNO, Z., MOUDRÝ, J. 2012 b: Differences in yield parameters of emmer in comparison with and new varieties of bread wheat. African Journal of Agricultural Research 7, 986-992.

KONVALINA, P., BRADOVÁ, J., CAPOUCHOVÁ, I., STEHNO, Z., MOUDRÝ, J. 2013: Baking quality and high molecular weight glutenin 
subunit composition of emmer wheat, old and new varieties of bread wheat. Romanian Agricultural Research 30, 83-89.

KREUZ, A., MARINOVA, E., SCHÄFER, E., WIETHOLD, J. 2005 Comparison of early Neolithic crop and weed assemblages from the Linearbandkeramik and the Bulgarian Neolithic cultures: differences and similarities. Vegetation History and Archaeobotany 14, 237-258.

KROUTIL, M., HEJTMÁNKOVÁ, A., LACHMAN, J. 2010: Effect of spring wheat (Triticum aestivum L.) treatment with brassinosteroids on the content of cadmium and lead in plant aerial biomass and grain. Plant, Soil and Environment 56, 43-50.

KUMAR, V., SINHA, A. K., MAKKAR, H. P. S., BECKER, K. 2010: Dietary roles of phytate and phytase in human nutrition: A review. Food Chemistry 120, 945-959.

KUNZOVÁ, E., HEJCMAN, M. 2009: Yield development of winter wheat over 50 years of FYM, N, P and K fertilizer application on black earth soil in the Czech Republic. Field Crops Research 111, 226-234.

KUNZOVÁ, E., HEJCMAN, M. 2010: Yield development of winter wheat over 50 years of nitrogen, phosphorus and potassium application on greyic Phaeozem in the Czech Republic. European Journal of Agronomy $33,166-174$.

MARINO, S., TOGNETTI, R., ALVINO, A. 2009: Crop yield and grain quality of emmer populations grown in central Italy, as affected by nitrogen fertilization. European Journal of Agronomy 31, 233-240.

MARINO, S., TOGNETTI, R., ALVINO, A. 2011: Effects of varying nitrogen fertilization on crop yield and grain quality of emmer grown in a typical Mediterranean environment in central Italy. European Journal of Agronomy 34, 172-180.

MEHLICH, A. 1984: Mehlich 3 soil test extractant: a modification of Mehlich 2 extractant. Communications in Soil Science \& Plant Analysis $15,1409-1416$.

PAVLŮ, V., GAISLER, J., PAVLŮ, L., HEJCMAN, M., LUDVÍKOVÁ, V. 2012: Effect of fertiliser application on plant species composition of Festuca rubra grassland under cutting management and its after effect under abandonment. Acta Oecologica 45, 42-49.

PEÑA-CHOCARRO, L., ZAPATA, L. 2003 : Crop-processing of hulled wheats, in: Anderson, P. C., Cummings, L. S., Schippers, T. S., Simone B. (Eds.): Le traitement des récoltes: un regard sur la diversité, du Néolithique au présent. Actes des XXIIIe rencontres Internationales d'archéologie et d'histoire d'Antibes, 17-19 octobre 2002, Antibes, Éditions APDCA. 1-10.
PLEINEROVÁ, I., PAVLŮ, I. 1979: Březno: osada z mladši doby kamenné v severozápadnich Čechách. Okresní muzeum, Ústí nad Labem.

PLEINEROVÁ, I. 2000: Die altslawischen Dörfer von Březno bei Louny. Okresní muzeum, Louny.

REYNOLDS, P. J. 1992: Crop yields of the prehistoric cereal types emmer and spelt: the worst option. In: Anderson, P. C. (Ed.): Préhistoire de l agriculture: nouvelles approches expérimentales et ethnographiques. CNRS, Paris, 383-393.

ŠRÁMEK, J., CAPOUCHOVÁ, I., STEHNO, Z. 2011: Characteristics of emmer landraces (Triticum dicoccum Schrank) and their suitability for organic farming. In: Pazderů, K. (Ed.): Seed and seedlings: scientific and technical seminar. Czech University of Life Sciences, Prague, 115-119.

STEHNO, Z. 2007: Emmer wheat Rudico can extend the spectra of cultivated plants. Czech Journal of Genetics and Plant Breeding 43, 113-115.

STEHNO, Z., KONVALINA, P., DOTLAČIL, L. 2008: Metodika pěstováni pšenice dvouzrnky. Crop Research Institute, Prague.

SUCHOWILSKA, E., WIWART, M., KANDLER, W., KRSKA, R. 2012: A comparison of macro- and mikroelement concentrations in the whole grain of four Triticum species. Plant, Soil and Environment 58, 141-147.

TEMPÍR, Z. 1976: K rozšireniu pestovania pšenice dvojzrnej (Triticum dicoccon Schrank) v zapadnich Karpatoch. Agrikultura 14. Nitra: Slovenske polnohospodarske muzeum, 21-36.

TEMPÍR, Z. 1982: Zemédělske plodiny a plevele z archeologickych nalezů $v$ Březně u Loun. Vědecké práce Zemědělského muzea 22, 121-195.

WYANT, K. A., CORMAN, J. R., ELSER, J. J. 2013: Phosphorus, food and our future. Oxford University Press.

ZAHARIEVA, M., AYANA, N. G., AL HAKIMI, A., MISRA, S. C., MONNEVEUX, P. 2010: Cultivated emmer wheat (Triticum dicoccon Schrank), an old crop with promising future: a review. Genetic resources and crop evolution 57, 937-962.

ZOU, C. Q., ZHANG, Y. Q., RASHID, A., RAM, H., SAVASLI, E., ARISOY, R. Z., ORTIZ-MONASTERIO, I., SIMUNJI, S., WANG, Z. H., SOHU, V., HASSAN, M., KAYA, Y., ONDER, O., LUNGU, O., YAQUB MUJAHID, M., JOSHI, A. K., ZELENSKIY, Y., ZHANG, F. S., CAKMAK, I. 2012: Biofortification of wheat with zinc through zinc fertilization in seven countries. Plant and Soil 361, 119-130. 
